\title{
HUBUNGAN PAPARAN KEBISINGAN DENGAN \\ KELUHAN SUBYEKTIF NON-AUDITORY PADA PEKERJA \\ KONSTRUKSI PT. X KABUPATEN GRESIK
}

\section{RELATIONSHIP OF NOISE EXPOSURE WITH NON-AUDITORIAL SUBJECTIVE COMPLAINTS IN PT. X CONSTRUCTION WORKERS GRESIK DISTRICTS}

\author{
Reny Indrayani ${ }^{1}$, Ragil Ismi Hartanti ${ }^{1}$, Anita Dewi Prahastuti Soejoso ${ }^{1}$, Nabila \\ H.Wahyuningtias ${ }^{1}$, Amirah J.L.Hasna ${ }^{1}$, Pratmasita R. Henary ${ }^{1}$, Ilham K. Fakhruddin. ${ }^{1}$, \\ Dwi E.Pratiwi ${ }^{1}$ \\ ${ }^{1}$ Jurusan Ilmu Kesehatan Masyarakat, Fakultas Kesehatan Masyarakat, Universitas Jember \\ Jl. Kalimantan no.37 68121 Jember, Jawa Timur, Indonesia \\ Email: renyindrayani.fkm@unej.ac.id
}

\begin{abstract}
Noise is all unwanted sounds produced from the production process and or work tools. at certain levels and times, noise can cause hearing loss and non-auditory complaints. Non-auditory complaints can be in the form of communication disorders, physiological disorders, and psychological disorders. This study aims to analyze the relationship between respondent characteristics and noise exposure factors with non-auditory complaints. This research is analytic type with cross sectional design. The independent variables of this study were the characteristics of respondents (age, sex, years of service, history of illness, use of ear protector) and noise exposure factors (duration of noise exposure and perception of noise exposure), while the dependent variable was non-auditory complaints. Researchers collected data using an online questionnaire. A population of 50 people and a sample of 30 respondents were construction workers at PT. X who provided services to the Smelter and Refinery section of PT.Y. Samples were selected by simple random sampling and data were analyzed by chi square test $(\alpha=0.05)$. The results showed that there was no relationship between the variables of age ( $p$-value $=0.301$ ), gender ( $p$-value $=0.909)$, history of disease $(p$-value $=0.909)$, years of service $(p$-value $=0.305)$, duration of exposure ( $p$-value $=0.198)$, use of ear protector $(p$-value $=0.233)$, and duration of exposure ( $p$-value $=0.198)$ with non-auditory complaints experienced by workers. The only variable that is associated with non-auditory complaints is the perception of noise exposure ( $p$-value $=0.021)$. The conclusion of this study is that, of all the independent variables (age, sex, years of service, history of illness, use of ear protector, duration of noise exposure and perception of noise exposure), only the perception of noise exposure is significantly related to non-auditory complaints. Suggestions for PT. $X$ is to conduct noise measurements regularly in all work areas, evaluate the use of ear protector, and carry out noise management programs.
\end{abstract}

Keywords: Noise exposure, contruction, non-auditory complaints, perceptions of noise exposure.

\begin{abstract}
Abstrak
Kebisingan adalah semua suara yang tidak dikehendaki yang bersumber dari proses produksi dan atau alat kerja yang pada tingkatan dan waktu tertentu mampu menimbulkan gangguan pendengaran dan keluhan non-auditory berupa gangguan komunikasi, gangguan fisiologis, dan gangguan psikologis. Penelitian ini bertujuan untuk menganalisis hubungan karakteristik responden dan faktor paparan kebisingan dengan keluhan non-auditory. Penelitian ini berjenis analitik dengan desain cross sectional. Variabel bebas penelitian ini adalah karakteristik responden (usia, jenis kelamin, masa kerja, riwayat penyakit, penggunaan Alat Pelindung Telinga) dan faktor paparan kebisingan (lama paparan kebisingan dan persepsi tentang paparan kebisingan), sedangkan variabel terikatnya adalah keluhan non-auditory. Peneliti mengumpulkan data dengan menggunakan angket online. Populasi sebanyak 50 orang dan sampel sebanyak 30 responden merupakan pekerja konstruksi di PT. X yang memberikan jasa ke bagian Smelter dan Refinery PT.Y. Sampel dipilih dengan simple random sampling dan data dianalisis dengan
\end{abstract}


uji chi square $(\alpha=0,05)$. Hasil penelitian menunjukkan bahwa tidak terdapat hubungan antara variabel usia $(p$-value $=0,301)$, jenis kelamin $(p$-value $=0,909)$, riwayat penyakit $(p$-value $=0,909)$, masa kerja $(p$ value $=0,305)$, lama paparan $(p$-value $=0,198)$, penggunaan Alat pelindung Telinga/APT $(p$-value $=$ $0,233)$, dan lama paparan ( $p$-value $=0,198)$ dengan keluhan non-auditory yang dialami pekerja. Satusatunya variabel yang terdapat hubungan dengan keluhan non-auditory adalah persepsi tentang paparan kebisingan $(p$-value $=0,021)$. Kesimpulan dari penelitian ini adalah, dari seluruh variabel bebas (usia, jenis kelamin, masa kerja, riwayat penyakit, penggunaan Alat Pelindung Telinga, lama paparan kebisingan dan persepsi tentang paparan kebisingan) hanya persepsi tentang paparan kebisingan yang berhubungan secara signifikan dengan keluhan non-auditory. Saran untuk PT. X adalah untuk melakukan pengukuran kebisingan secara berkala di seluruh area kerja, melakukan evaluasi terhadap penggunaan APT, dan melaksanakan program manajemen kebisingan.

Kata kunci: Paparan kebisingan, konstruksi, keluhan non-auditory, persepsi tentang paparan kebisingan.

\section{PENDAHULUAN}

Suara diartikan sebagai getaran yang bergerak melalui udara atau media lain yang dapat didengar Ketika mencapai telinga. Kebisingan didefinisikan sebagai suara yang tidak diinginkan dan/atau berbahaya (Fink, 2019). Kebisingan menjadi salah satu bahaya fisik yang banyak mengintai pekerja yang bekerja di sektor industri. Paparan kebisingan di tempat kerja dalam waktu yang lama secara terus menerus tanpa ada upaya penanganan maupun pencegahan mampu menimbulkan dua jenis efek, yakni gangguan pada sistem pendengaran (auditory effect) dan gangguan non pendengaran (non-auditory). Non-auditory terdiri atas tiga aspek yakni gangguan fisiologis, gangguan psikologis, dan gangguan komunikasi (Amar, et al., 2019).

Gangguan psikologis yang diakibatkan oleh kebisingan memiliki ciri berupa peningkatan emosi, rasa tidak nyaman, kurang konsentrasi, stress, dan susah tidur. Gangguan psikologis akibat kebisingan bergantung pada intensitas, frekuensi, periode, lama suara bising, dan tidak teraturnya suara kebisingan (Gunawan \& Marsum, 2015). Gangguan komunikasi disebabkan oleh masking effect (bunyi yang menutupi pendengaran dengan jelas). Akibat dari masking effect di industri yakni pekerja hanya dapat berkomunikasi dengan pekerja lain dengan cara memperkeras suaranya atau berteriak (Basner et al., 2014). Gangguan komunikasi dapat mengakibatkan gangguan konsentrasi, perubahan kepribadian, menurunkan kapasitas kerja, menimbulkan gangguan terkait hubungan antar pekerja,hingga menimbulkan reaksi stress. Menurut Environmental Expert Council (EEC) of Germany, kebisingan merupakan sumber utama dari munculnya stres parah. Data yang dipublikasikan oleh Labour Force Survey (LFS) menunjukkan bahwa pada tahun 2015/2016 sebanyak 488.000 pekerja di Britani Raya mengalami stress kerja, depresi maupun cemas dengan prevalance rate mencapai 1510 per 100.000 pekerja. Saat ini di Indonesia belum terdapat data pasti yang menunjukkan jumlah pekerja yang mengalami stres, khususnya stres yang diakibatkan oleh paparan kebisingan. Data yang tersedia hanya terbatas pada prevalensi gangguan mental termasuk stress di dalamnya, dan bukan pada pekerja melainkan pada populasi masyarakat umum. Hasil Riset Kesehatan Dasar (Riskesdas) 2013, menunjukkan prevalensi gangguan mental di Indonesia sebanyak 6\%.

Beberapa penelitian menunjukkan adanya keterkaitan antara paparan kebisingan dengan tingkat stres pekerja. Seperti penelitian yang dilakukan (Apladika et al., 2016) yang menyatakan bahwa dari $95,5 \%$ pekerja yang terpapar kebisingan diatas NAB sebanyak 88,6\% diataranya mengalami stress kerja. Penelitian yang dilakukan (Hiola dan Sidiki, 2016) juga mengatakan bahwa terdapat hubungan yang signifikan antara tingkat kebisingan dengan stress pada pekerja.

PT. X merupakan perusahaan menyediakan jasa konstruksi. Jasa kosntruksi yang disediakan oleh PT.X dipergunakan oleh PT. Y untuk membantu pelaksanaan operasional perusahaannya. PT.Y merupakan perusahaan yang didirikan pada bulan Februari 1996 dan mulai beroperasi diakhir tahun 1998. PT. Y merupakan perusahaan yang bergerak dibidang peleburan tembaga dan kilang tembaga yang ada di Indonesia dan berada di Kabupaten Gresik, Jawa Timur. Teknologi yang digunakan oleh PT. Y adalah teknologi mitsubishi. Pada PT.Y terdiri atas 3 plant yakni plant acid, plant refinery dan plant smelter. Plant yang menjadi pusat 
kebisingan terletak di plant bagian refinery dan smelter (Antonius, 2017).

Peleburan tembaga yang dilakukan oleh PT.Y yang menggunakan jasa pekerja PT.X dilakukan setiap hari sehingga menjadikan penggunaan dari mesin-mesin maupun proses kerja yang menghasilkan intensitas paparan kebisingan yang dihasilkan semakin besar. Sumber kebisingan berasal dari mesin yang digunakan pada saat proses smelting dan refinery. Paparan kebisingan yang semakin besar tersebut membutuhkan upaya pencegahan sehingga resiko non-auditory akibat kebisingan dapat diminimalisir. Berdasarkan uraian diatas penelitian ini bertujuan untuk menganalisis pengaruh paparan kebisingan terhadap keluhan non-auditory (gangguan fisiologis, gangguan psikologis, dan gangguan komunikasi) pada pekerja jasa konstruksi PT. X yang bekerja di bagian smelter dan refinery PT.Y yang berlokasi di Kabupaten Gresik.

\section{METODE PENELITIAN}

Penelitian ini merupakan penelitian analitik observasional dengan desain penelitian crossectional dengan pengumpulan data variabel yang diteliti dilakukan pada waktu yang bersamaan. Penelitian ini dilakukan pada pekerja jasa konstruksi PT. X yang bekerja di bagian smelter dan refinery PT.Y di Kabupaten Gresik pada April-Juni 2020. Populasi penelitian sebesar 50 orang, dengan perhitungan menggunakan rumus Slovin, didapatkan sampel penelitian sebanyak 33 orang. Teknik pengambilan sampel menggunakan simple random sampling, dengan kriteria inklusi pekerja telah bekerja minimal selama 6 bulan. Variabel bebas terdiri dari karakteristik responden (usia, jenis kelamin, masa kerja, riwayat penyakit dan penggunaan APT) dan faktor paparan kebisingan (lama paparan kebisingan dan persepsi tentang paparan kebisingan), sedangkan variabel terikatnya adalah keluhan non-auditory.

Keluhan non-auditory merupakan gabungan dari gangguan fisiologis, gangguan psikologis, dan gangguan komunikasi yang secara subjektif dirasakan oleh responden akibat paparan bising di lingkungan/tempat kerja. Ketiga jenis gangguan tersebut secara teori berkaitan satu sama lain sehingga pengukurannya disatukan dalam sebuah instrumen wawancara yang terdiri dari 15 poin pertanyaan dan dikategorikan menjadi keluhan ringan dan berat. Keluhan non-auditory dikategorikan ringan apabila skor masuk pada rentang 1-15, dan berat jika skor penilaian masuk pada rentang 16-30. Skor didapatkan dengan mengalikan antara kemunculan gejala dan frekuensi responden merasakan gejala tersebut. Instrumen yang digunakan dalam penelitian ini berupa angket online dalam bentuk Google Form guna menyikapi kondisi pandemi Covid-19. Analisis data penelitian ini menggunakan uji Chi Square dan disajikan dalam bentuk tabel.

\section{HASIL DAN PEMBAHASAN}

\section{Hasil Penelitian \\ Karakteristik Responden}

Hasil pengumpulan data tentang karakteristik responden yang terdiri dari usia, jenis kelamin, masa kerja, riwayat penyakit dan penggunaan APT ditampilkan dalam Tabel 1.

Tabel 1. Distribusi Karakteristik Responden

\begin{tabular}{|c|c|c|}
\hline \multirow{2}{*}{ Variabel } & \multicolumn{2}{|c|}{ Frekuensi } \\
\hline & $\mathbf{N}$ & $\%$ \\
\hline \multicolumn{3}{|l|}{ Usia } \\
\hline$<40$ & 24 & 72,7 \\
\hline$\geq 40$ & 9 & 27,3 \\
\hline \multicolumn{3}{|l|}{ Jenis Kelamin } \\
\hline Laki - Laki & 30 & 90,9 \\
\hline Perempuan & 3 & 9,1 \\
\hline \multicolumn{3}{|l|}{ Masa Kerja } \\
\hline$<5$ Tahun & 21 & 63,6 \\
\hline$\geq 5$ Tahun & 12 & 36,4 \\
\hline \multicolumn{3}{|l|}{ Riwayat Penyakit } \\
\hline Ada & 3 & 9,1 \\
\hline Tidak Ada & 30 & 90,9 \\
\hline \multicolumn{3}{|l|}{ Penggunaan APT } \\
\hline$\geq 4$ hari/minggu & 28 & 84,8 \\
\hline Tidak Menggunakan & 5 & 15,2 \\
\hline
\end{tabular}

Tabel 1 menyajikan informasi bahwa sebagian besar responden berusia kurang dari 40 tahun (72,7\%). Tabel 1 menunjukkan bahwa mayoritas responden berjenis kelamin laki-laki (90,9\%). Tabel 1 memperlihatkan bahwa sebagian besar responden memiliki masa kerja kurang dari 5 tahun $(63,6 \%)$. Tabel 1 menginformasikan bahwa Sebagian besar responden tidak memiliki riwayat penyakit diabetes militus, kardiovaskuler dan hiperlipedemia $(90,9 \%)$. Tabel 1 memberikan gambaran bahwa mayoritas responden telah menggunakan APT (sumbat telinga dan tutup telinga) hampir setiap hari dalam seminggu terakhir (setidaknya 4 hari kerja) dengan persentase sebesar $84,8 \%$. 


\section{Paparan Kebisingan}

Pengumpulan data tentang paparan kebisingan yang terdiri dari lama paparan dan persepsi tentang kebisingan yang dilakukan dengan wawancara online menggunakan angket dengan media Google form kepada seluruh responden ditampilkan dalam Tabel 2.

Tabel 2. Distribusi Frekuensi Responden Berdasarkan Paparan Kebisingan

\begin{tabular}{lcc}
\hline \multirow{2}{*}{ Variabel } & \multicolumn{2}{c}{ Frekuensi } \\
\cline { 2 - 3 } & n & \% \\
\hline Lama Paparan & 23 & 69,7 \\
< 4 jam/Hari & 10 & 30,3 \\
$\geq$ 4 Jam/Hari & \\
Persepsi tentang Paparan Kebisingan & \\
Terganggu & 16 & 48,5 \\
Tidak Terganggu & 17 & 51,5 \\
\hline
\end{tabular}

Tabel 2 menunjukkan bahwa sebagian besar responden terpapar kebisingan kurang dari 4 jam per hari $(69,7 \%)$. Tabel 2 memperlihatkan bahwa responden yang merasa terganggu dan yang tidak merasa terganggu oleh paparan kebisingan menunjukkan proporsi yang hampir sama dengan persentasi masing-masing sebesar $48,5 \%$ dan $51,5 \%$.

\section{Keluhan Non-Auditory}

Keluhan non-auditory diukur dengan 15 pertanyaan yang berisi tentang gejala terjadinya gangguan fisiologis, gangguan psikologis, dan gangguan komunikasi yang secara subjektif dirasakan oleh responden. Hasil penelitian tentang keluhan non-auditory ditampilkan pada Tabel 3.

Tabel 3. Distribusi Frekuensi Responden Berdasarkan Keluhan Non-Auditory

\begin{tabular}{lcc}
\hline \multirow{2}{*}{ Keluhan Non auditory } & \multicolumn{2}{c}{ Frekuensi } \\
\cline { 2 - 3 } & N & \% \\
\hline Keluhan Ringan & 12 & 36,4 \\
Keluhan Berat & 21 & 63,6 \\
\hline
\end{tabular}

Tabel 3 menginformasikan bahwa sebagian besar responden mengalami keluhan nonauditory berat dengan persentase sebesar $63,6 \%$. Keluhan non-auditory dikategorikan ringan apabila skor penilaian berada pada rentang 1-15, dan berat jika skor penilaian berada pada rentang 16-30. Skor didapatkan dengan mengalikan antara kemunculan gejala dengan frekuensi responden merasakan gejala tersebut. Gangguan fisiologi yang dirasakan responden dapat berupa sakit kepala, kesulitan mengawali tidur, kelelahan, gangguan pencernakan, dan gangguan keseimbangan elektrolit tubuh.
Gangguan psikologi meliputi rasa ketidaknyamanan, keluhan kesulitan konsentrasi, perasaan mudah marah/jengkel, perasaan mudah curiga dan bingung. Gangguan komunikasi berkaitan dengan gangguan kejelasan suara akibat masking effect sehingga seseorang sulit untuk menyampaikan informasi pada orang lain dan cenderung melakukan usaha tambahan untuk menyampaikan atau menerima informasi dari orang lain. Keluhan pada tingkat ringan umumnya sulit diamati dari luar, sedangkan untuk keluhan berat umunya gangguan psikologis dan komunikasi dapat diamati secara jelas. Misalnya, responden mudah marah, bingung, memerlukan usaha tambahan dalam komunikasi di tempat kerja.

Tabel 4. Hasil Analisis Bivariat

\begin{tabular}{|c|c|c|c|c|}
\hline \multirow[t]{2}{*}{ Variabel } & \multicolumn{2}{|c|}{$\begin{array}{c}\text { Keluhan Non- } \\
\text { auditory }\end{array}$} & \multirow{2}{*}{$\begin{array}{c}\text { Tot } \\
\text { al }\end{array}$} & \multirow{2}{*}{$\begin{array}{c}p- \\
\text { value }\end{array}$} \\
\hline & Berat & Ringan & & \\
\hline \multicolumn{5}{|c|}{ Karakteristik Responden } \\
\hline \multicolumn{5}{|c|}{ Usia } \\
\hline$<40$ Tahun & 14 & 10 & 24 & \multirow{2}{*}{0,301} \\
\hline$\geq 40$ Tahun & 7 & 2 & 9 & \\
\hline \multicolumn{5}{|l|}{ Jenis Kelamin } \\
\hline Laki-Laki & 19 & 11 & 30 & \multirow{2}{*}{0,909} \\
\hline Perempuan & 2 & 1 & 3 & \\
\hline \multicolumn{5}{|l|}{ Masa Kerja } \\
\hline$<5$ Tahun & 12 & 9 & 21 & \multirow{2}{*}{0,305} \\
\hline$\geq 5$ Tahun & 9 & 3 & 12 & \\
\hline \multicolumn{5}{|c|}{ Riwayat Penyakit } \\
\hline Ada & 2 & 1 & 3 & \multirow{2}{*}{0,909} \\
\hline Tidak Ada & 19 & 11 & 30 & \\
\hline \multicolumn{5}{|c|}{ Penggunaan APT } \\
\hline$\geq 4$ hari/minggu & 19 & 9 & 28 & \multirow[b]{2}{*}{0,233} \\
\hline $\begin{array}{l}\text { Tidak } \\
\text { Menggunakan }\end{array}$ & 2 & 3 & 5 & \\
\hline \multicolumn{5}{|c|}{ Paparan Kebisingan } \\
\hline \multicolumn{5}{|c|}{ Lama Paparan } \\
\hline$<4$ Jam/hari & 13 & 10 & 23 & \multirow{2}{*}{0,198} \\
\hline$\geq 4$ Jam/hari & 8 & 2 & 10 & \\
\hline \multicolumn{5}{|c|}{ Persepsi Tentang Paparan Kebisingan } \\
\hline Terganggu & 14 & 3 & 17 & \multirow[b]{2}{*}{0,021} \\
\hline $\begin{array}{l}\text { Tidak } \\
\text { Terganggu }\end{array}$ & 7 & 9 & 16 & \\
\hline
\end{tabular}

\section{Hubungan Variabel dengan Keluhan Non- auditory}

Hasil analisis bivariat menggunakan uji chi square pada tabel 4 menunjukkan bahwa tidak terdapat hubungan antara usia $(\mathrm{p}=0,301)$, jenis kelamin $(p=0,909)$, masa kerja $(p=0,305)$, riwayat penyakit $(\mathrm{p}=0,909)$, penggunaan APT $(\mathrm{p}=0,233)$, dan lama paparan kebisingan $(\mathrm{p}=$ 0,198), dengan keluhan non-auditory. Tabel 4 menunjukkan bahwa terdapat hubungan antara 
persepsi tentang paparan kebisingan dengan keluhan non-auditory $(\mathrm{p}=0,021)$.

\section{Pembahasan \\ Hubungan Usia dengan Keluhan Non- auditory}

Gangguan kesehatan akibat paparan kebisingan dapat dicegah atau diminimalisir dengan mengendalikan intensitas kebisingan di bawah nilai ambang batas (NAB) yang berlaku. Intensitas kebisingan yang diijinkan memapar pekerja di Indonesia diatur dalam Permenaker Nomor 5 Tahun 2018 tentang Kesehatan dan Keselamatan Lingkungan Kerja, yakni 85 dBA. Nilai tersebut berlaku untuk paparan 8 jam kerja sehari dan 40 jam kerja dalam satu minggu. Berdasarkan hasil penelitian diketahui bahwa tidak terdapat hubungan antara usia responden dengan keluhan non-auditory pada pekerja jasa konstruksi PT. X yang bekerja di bagian smelter dan refinery pada PT.Y dengan nilai $\mathrm{p}=0,301$. Hasil penelitian ini tidak sejalan dengan penelitian Rahayu dan Pawenang yang menyatakan bahwa terdapat hubungan antara usia dengan keluhan non pendengaran (Rahayu dan Pawenang, 2016). Teori mengatakan bahwa usia merupakan salah satu faktor yang memicu munculnya keluhan subyektif pada pekerja. Usia menjadi faktor intrinsik yang berasal dari dalam tubuh pekerja. Hal ini berkaitan dengan fungsi fisiologis tubuh pekerja. Semakin bertambah umur pekerja akan menurunkan fungsi fisiologis tubuh. Selain itu, pada usia yang semakin bertambah akan terjadi penurunan kepekaan terhadap rangsangan suara. Setelah usia 30 tahun atau lebih, pada umumnya kapasitas fisik tenaga kerja seperti penglihatan, pendengaran dan kecepatan reaksi cenderung menurun. Usia berbanding lurus dengan kapasitas kerja 25 tahun yang dianggap sebagai usia puncak, sedangkan 25-60 tahun terjadi penurunan kapasitas fisik 25\% untuk kekuatan otot, $60 \%$ untuk kemampuan sensoris dan motoris (Ariestyajuni, 2019).

Hasil penelitian ini sejalan dengan penelitian Sriwahyudi et al. yang menyatakan bahwa tidak terdapat hubungan antara usia dengan keluhan non-auditory pada instalasi laundry (Sriwahyudi et al., 2014). Hal yang sama diungkapkan oleh hasil penelitian Fathimah et al. yang menyatakan bahwa tidak terdapat hubungan antara usia dengan keluhan non-auditory (Fathimah et al., 2018). Keluhan kesehatan non-auditory tidak hanya dipengaruhi oleh usia, tetapi juga dipengaruhi karena intensitas bising, masa kerja, lama kerja dan penggunaan alat pelindung telinga. Selain itu, terdapat responden yang berusia tua dengan masa kerja lebih singkat dan responden berumur muda dengan masa kerja lebih Panjang, begitu pula dengan faktor lain seperti masa kerja, dan lama paparan yang berbeda pada masing-masing usia sehingga memunculkan tidak terdapatnya hubungan antara usia dengan keluhan nonauditory pada unit penelitian.

\section{Hubungan Jenis Kelamin dengan Keluhan Non-auditory}

Penelitian ini mendapati bahwa tidak terdapat hubungan antara jenis kelamin dengan keluhan non-auditory pada pekerja jasa konstruksi PT. X yang bekerja di bagian smelter dan refinery pada PT.Y ( $\mathrm{p}=0,909)$. Hasil penelitian ini bertentangan dengan penelitian Yang et al., dimana wanita lebih sensitif terhadap intensitas kebisingan dibandingkan dengan pria (Yang et al., 2017). Selain memiliki sensitivitas terhadap kebisingan yang lebih besar, wanita juga dilaporkan memiliki kualitas tidur yang lebih buruk dan memiliki prevalensi imsomnia lebih tinggi dibandingkan dengan pria dalam kaitannya dengan dampak paparan kebisingan (Tang, 2017)

Hasil penelitian ini sejalan dengan penelitian Tantana yang menyatakan bahwa jenis kelamin dan intensitas kebisingan tidak berhubungan dengan risiko ketulian pada mahasiswa fakultas Seni Pertunjukan pemain gamelan Bali (Tantana, 2014). Hal yang sejalan diutarakan pula oleh Nooruzian et al., yang mengemukakan bahwa gangguan pendengaran berupa tinnitus tidak berhubungan dengan jenis kelamin responden (Nooruzian et al., 2014). Park et al., melalui penelitiannya mengatakan bahwa tidak ada perbedaan sensitivitas di antara laki-laki dan perempuan, dan tidak terdapat hubungan antara jenis kelamin dengan anxiety yang ditimbulkan dari paparan kebisingan (Park et al., 2017). Hill menyatakan bahwa memang terdapat penelitian yang menyebutkan bahwa wanita memiliki sensitivitas yang lebih besar terhadap kebisingan (Hill, 2012). Hal ini disebabkan oleh adanya bukti bahwa wanita memiliki sistem pendengaran yang lebih baik daripada pria berkaitan dengan perbedaan nada dan kenyaringan suara yang pada gilirannya dipengaruhi oleh faktor perbedaan hormonal (Rammsayer dan Troche, 2011). Di sisi lain, tidak sedikit penelitian yang menyebutkan hal yang sebaliknya (sensitivitas terhadap 
kebisingan tidak berbeda berdasarkan jenis kelamin). Hal ini karena sensitivitas kebisingan sebagian besar dianggap berkaitan dengan sikap/persepsi yang melibatkan pikiran dan emosi ketimbang hasil dari ketajaman sistem pendengaran. Oleh karena itu, mekanisme yang mendasari hubungan antara gender, sensitivitas kebisingan dan kesehatan belum bisa secara jelas dibuktikan (Hill, 2012).

\section{Hubungan Masa Kerja dengan Keluhan Non- auditory}

Hasil uji dalam penelitian ini menunjukan bahwa tidak terdapat hubungan antara masa kerja dengan keluhan non-auditory pekerja jasa konstruksi PT. $X$ dengan nilai $p=0,305$. Hal ini berbeda dengan yang disampaikan Fredriksson et al. dalam penelitiannya yang menyebutkan bahwa semakin panjang masa kerja seseorang, maka keluhan kelelahan yang disebabkan oleh paparan kebisingan yang dirasakan akan semakin parah (Fredriksson et al., 2014). Masa kerja umumnya berkaitan erat dengan akumulasi paparan yang telah diterima pekerja selama bekerja, sehingga sangat memungkinkan bagi pekerja dengan masa kerja yang cukup lama untuk mengalami berbagai gangguan maupun dampak akibat paparan kebisingan baik secara psikologis maupun fisiologis (Sudirman et al., 2014) .

Perbedaan temuan dalam penelitian ini dengan penelitian sebelumnya dapat dimungkinkan oleh adanya perbedaan intensitas kebisingan di beberapa area kerja di lokasi penelitian. Berdasarkan hasil observasi diketahui bahwa pekerja dengan masa kerja lebih pendek (< 5 tahun), ditempatkan pada lokasi dengan volume pekerjaan yang lebih padat dan lebih banyak menggunakan peralatan yang menghasilkan kebisingan dibandingkan dengan pekerja dengan masa kerja lebih lama $(\geq 5$ tahun). Hasil penelitian ini sejalan dengan penelitian yang dilakukan oleh Fathimah et al., yang menyatakan tidak terdapat hubungan antara masa kerja dengan keluhan non-auditory pada pekerja bagian weaving di PT. Unitex. Lebih lanjut Fathimah et al. menyebutkan bahwa tidak menutup kemungkinan pekerja dengan masa kerja $<5$ tahun mengalami penurunan daya dengar akibat pajanan bising dengan intensitas sangat tinggi dan waktu pajanan harian melebihi standar yang diijinkan (Fathimah et al., 2018).

\section{Hubungan Riwayat Penyakit dengan Keluhan Non-auditory}

Munzel menjelaskan bahwa dalam penelitian terbaru pada 62.000 orang ditemukan bahwa kebisingan lalu lintas berkaitan dengan tingginya kadar glukosa puasa, stres dan gangguan tidur. Konsekuensi ini akan lebih parah dialami oleh seseorang dengan riwayat penyakit diabetes dan dapat meningkatkan risiko diabetes pada orang normal. Hadad et al. menyebutkan bahwa paparan kebisingan dengan intensitas rendah secara terus menerus dapat menyebabkan gangguan non-auditory berupa tekanan mental (Hadad et al., 2019). Mekanisme yang mendasari stres mental yang diinduksi oleh kebisingan berpusat pada peningkatan kadar hormon stres, tekanan darah, dan detak jantung, yang pada gilirannya mendukung perkembangan penyakit serebrokardiovaskular seperti stroke, hipertensi arteri, penyakit jantung iskemik, dan infark miokard yang risikonya lebih tinggi pada seseorang dengan riwayat penyakit kardiovaskuler.

Penelitian-penelitian

tersebut berseberangan dengan penelitian ini dimana variabel riwayat penyakit (diabetes militus, kardiovaskuler dan hiperlipedemia) dalam penelitian ini terbukti tidak berhubungan dengan keluhan non-auditory responden $(\mathrm{p}=0,909)$. Ketidakselarasan ini dapat dimungkinkan terjadi apabila pajanan kebisingan di area kerja memiliki intensitas yang tinggi sehingga baik pekerja yang dengan atau tanpa riwayat penyakit, sama-sama mengalami keluhan nonauditory. Pendapat ini didukung oleh Babisch yang mengatakan bahwa memang terdapat hubungan antara riwayat penyakit (kardiovaskuler) dengan sensitivitas terhadap pajanan kebisingan, akan tetapi faktor terpenting yang berperan terhadap munculnya gangguan kesehatan adalah intensitas pajanan kebisingan itu sendiri (Babisch, 2010).

\section{Hubungan Penggunaan APT dengan Keluhan Non-auditory}

APT yang disediakan untuk digunakan oleh pekerja berupa sumbat telinga (ear plug) dan tutup telinga (ear muff). Hasil uji statistik antara variabel penggunaan APT dengan keluhan nonauditory akibat kebisingan pada pekerja jasa konstruksi PT. X yang ditampilkan pada Tabel 4, diketahui bahwa tidak terdapat hubungan antara penggunaan APT dengan keluhan non-auditory dengan nilai $\mathrm{p}=0,233$. Hal ini tidak sejalan dengan hasil penelitian Astuti yang menyatakan bahwa penggunaan APD untuk melindungi telinga berpengaruh secara signifikan terhadap 
keluhan non-auditory para pekerja (Astuti, 2019). Sumbat telinga berupa kapas dapat meredam kebisingan sebesar 10-15 dBA (Darlani dan Sugiharto, 2017). APT berupa sumbat telinga (ear plug) secara teori dapat mengurangi kebisingan 8-30 dBA dan tutup telinga (ear muff) dapat mereduksi kebisingan 25-40 dBA (Panggeleng, 2018).

Alasan perbedaan temuan penelitian ini dengan penelitian sebelumnya adalah adanya kemungkinan bahwa APT baik berupa sumbat telinga (ear plug) dan tutup telinga (ear muff) berkurang efektivitasnya karena tidak sepenuhnya digunakan dengan benar, ukuran dan bentuk APT yang tidak sesuai dengan penggunanya, atau kondisi APT kurang baik/rusak (Eryani et al., 2017). APT dapat rusak akibat kurang tepatnya perawatan dan penyimpanan, serta masa penggunaannya melampaui standar. Tutup telinga (ear muff) misalnya, lama kelamaan bantalan (chusion) pada tutup telinga dapat mengeras akibat bereaksi dengan minyak atau keringat pada permukaan kulit penggunanya. Kondisi yang demikian dapat memungkinkan gelombang suara masuk ke dalam telinga melalui celah antara bantalan dengan kulit penggunanya (Sari, 2010). Alasan yang hampir sama pernah dikemukakan oleh Wardani et al. dimana pada hasil penelitiannya juga didapati hasil bahwa tidak terdapat hubungan antara penggunaan APD dengan keluhan subjektif non-auditory pada pekerja di PT. X di Kabupaten Probolinggo (Wardani et al., 2020) .

\section{Hubungan Lama Paparan Kebisingan dengan Keluhan Non-auditory}

Uji korelasi antara variabel lama paparan dengan keluhan non-auditory pada pekerja jasa konstruksi PT. X menyatakan bahwa tidak terdapat hubungan antara lama paparan dengan keluhan non-auditory $(\mathrm{p}=198)$. Hal ini agaknya bertentangan dengan hasil penelitian Elfiza yang menyatakan bahwa terdapat hubungan antara lama paparan kebisingan dengan peningkatan tekanan darah sebagai salah satu gejala fisiologis (non-auditory) (Elfiza, 2017). Kendati demikian, temuan penelitian Fathimah et al. (2018) dan Indriyanti et al. selaras dengan penelitian ini, dimana kedua penelitian tersebut menyatakan bahwa tidak terdapat hubungan yang signifikan antara lama paparan kebisingan dengan gejala atau keluhan non-auditory (Indriyanti et al., 2019).
Apabila dihubungkan dengan gangguan pendengaran/peningkatan ambang dengar, berbagai penelitian menunjukkan variabel lama paparan kebisingan menunjukkan adanya hubungan yang signifikan. Penelitian Phillips et al., mengemukakan bahwa lama paparan berhubungan signifikan dengan gangguan pendengaran akibat kebisingan (Phillips et al., 2010). Lebih lanjut, Rakhmawati et al. (2018) menyatakan bahwa terdapat hubungan antara lama paparan kebisingan dengan kenaikan ambang dengar pekerja penggilingan padi (Rakhmawati et al., 2018). Temuan ini mendorong kepercayaan bahwa kenaikan ambang dengar (tuli sensoneural) mewakili faktor adaptasi seseorang terhadap paparan kebisingan (Gani et al., 2018). Proses adaptasi inilah yang kemungkinan menaikkan ambang toleransi seseorang terhadap keluhan nonauditory akibat paparan kebisingan sehingga lama paparan kebisingan tidak berhubungan dengan munculnya keluhan non-auditory. Proses adaptasi terhadap paparan kebisingan seperti yang diungkapkan penulis, masih memerlukan penelitian lebih lanjut.

Alasan lain yang mendukung temuan tidak terdapatnya hubungan antara lama paparan kebisingan dengan keluhan non-auditory adalah karena meski terdapat perbedaan lama paparan kebisingan, akan tetapi lama paparan seluruh pekerja tidak melebihi 8 jam kerja seperti yang ditetapkan dalam Nilai Ambang Batas (NAB) kebisingan yang diatur dalam Permenaker Nomor 5 Tahun 2018 tentang Keselamatan dan Kesehatan Kerja lingkungan Kerja.

\section{Hubungan Persepsi tentang Kebisingan dengan Keluhan Non-auditory}

Berdasarkan hasil penelitian diketahui bahwa terdapat hubungan antara persepsi kebisingan dengan keluhan non-auditory pada pekerja jasa konstruksi PT. X yang bekerja di bagian smelter dan refinery pada PT.Y. Hal tersebut sejalan dengan hasil penelitian Fathimah et al. (2018) bahwa persepsi kebisingan berpengaruh terhadap tingkat keluhan non-auditory yang dialami oleh pekerja.

Robbins menyatakan bahwa persepsi merupakan proses penafsiran terhadap suatu hal yang ditangkap oleh panca indera individu agar dapat disimpulkan makna yang dimaksud oleh lingkungan individu. Persepsi dapat membuat individu mampu untuk mengenali lingkungannya serta dapat mempengaruhi atau dipengaruhi oleh lingkungannya (Robbins, 
2002). Adapun interaksi yang terjadi antara individu dan lingkungan mampu menimbulkan persepsi yang berbeda-beda pada individu. Menurut Hernayanti et al. (2018), persepsi kebisingan memiliki pengaruh terhadap kejadian gangguan non pendengaran (non-auditory effect) yang dialami oleh pekerja seperti gangguan komunikasi, gangguan tidur, dan gangguan psikologis (Hernayanti et al., 2018). Penelitian yang dilakukan oleh Pratiwi et al. (2013) menyatakan terdapat hubungan persepsi kerja dengan stress yang dirasakan pekerja. dimana semakin tinggi persepsi terhadap kebisingan, semakin tinggi tingkat stress yang masuk kedalam gangguan aspek psikologi.

\section{Keterbatasan Penelitian}

Keterbatasan penelitian ini adalah tidak dapat dilakukannya pengambilan data secara langsung terutama terkait dengan pengukuran intensitas kebisingan di area kerja PT. X dikarenakan adanya pembatasan sosial berskala besar (PSBB) untuk mencegah meluasnya Pandemi Covid-19 yang terjadi saat penelitian berlangsung. Berdasarkan hasil wawancara dengan perwakilan PT. X diketahui bahwa tidak terdapat data sekunder tentang pengukuran kebisingan yang dapat menunjang hasil penelitian.

\section{KESIMPULAN DAN SARAN}

\section{Kesimpulan}

Berdasarkan hasil dan pembahasan penelitian, dapat ditarik kesimpulan bahwa:

1. Faktor karakteristik individu yang meliputi usia, jenis kelamin, masa kerja, riwayat penyakit dan penggunaan APT, seluruhnya tidak berhubungan secara signifikan dengan keluhan non-auditory pada pekerja jasa konstruksi PT. X di Kabupaten Gresik.

2. Faktor paparan kebisingan berupa lama paparan tidak memiliki hubungan dengan keluhan non-auditory, sedangkan persepsi tentang paparan kebisingan memiliki hubungan yang signifikan dengan keluhan non-auditory pada pekerja jasa konstruksi PT. X di Kabupaten Gresik.

\section{Saran}

Saran yang dapat diberikan pada PT. X berdasarkan hasil dan temuan penelitian ini adalah:

1. Melakukan pengukuran kebisingan secara berkala di seluruh area kerja.
2. Melakukan evaluasi terhadap penggunaan APT

3. Melaksanakan program manajemen kebisingan yang terdiri dari : a) mengidentifikasi masalah kebisingan, b) merencanakan mitigasi kebisingan dan langkah-langkah pengendalian, c) implementasi dan operasi pengendalian kebisingan, d) penilaian dan tindakan korektif, e) tinjauan berkala, dan f) peningkatan berkelanjutan.

\section{DAFTAR RUJUKAN}

1] Alpadika, Denny, HM., Wahyuni, I. 2016. Hubungan Paparan Kebisingan terhadap Stres Kerja pada Porter Ground Handling di Kokapura Ahmad Yani Semarang. Jurnal Kesehatan Masyarakat, 4(4), 630-636.

2] Amar, D. M., Dina, L., \& Khairul, N. 2019. Hubungan Kebisingan dengan Kejadian Hearing Loss dan Stress Kerja di Area Produksi PT.X. Jurnal Kesehatan 5(1), 112.

3] Anies. 2010 . Seri Kesehatan Umum : Penyakit Akibat Kerja. Jakarta: PT. Elex Media Komputindo.

4] Antonius, P. 2017. Smelting Furnace Melt Zone Wall Modification to Cope Higher Production Rate Operation. IPMC, 1-7.

5] Ariestyajuni, A. 2019. Dampak Pajanan Kebisingan Mesin Ekstruder terhadap Gangguan Komunikasi pada Pekerja PT.X Sidoarjo. Medical Technology and Public Health Journal 3 (1), 17-22.

6] Astuti, S. 2019. Hubungan Persepsi Kebisingan Dengan Keluhan Non Auditory Pada Tenaga Kerja Bagian Produksi Plant 3-4 Pt. I Tahun 2019. Disertasi, p. Jakarta: Universitas Pembangunan Nasional Veteran Jakarta.

7] Babisch, W. 2010. Noise Sensitivity in Cardiovascular Noise Studies. Paper at the Meeting of the Inter-Noise.

8] Basner, M. Babisch, W., Davis, A., Brink, M., Clark, C., Jenssen, S., Stansfeld, S. 2014. Auditory and Non Auditory Effect of Noise on Health. The Lancet, 383 (9925), 1325-1332.

9] Darlani dan Sugiharto. 2017. Kebisingan dan Gangguan Psikologis Pekerja Weaving Loom dan Inspection PT. Primatexco 
Indonesia. Jurnal of Health Education, 2(2), 130-137.

10] Elfiza, R., Marliyawati, D. 2017. Hubungan antara Lamanya Paparan Bising dengan Gangguan Fisiologis dan Pendengaran pada Pekerja Insustri Tekstil. Jurnal Kedokteran Diponegoro, 8(2), 1196-1207.

11] Eryani, YM., Wibowo, CA., Saftarina, F. 2017. Faktor Risiko Terjadinya Gangguan Pendengaran Akibat Bising. Medula, 7(4), 112-117.

12] Fathimah, A., Ramadhani, TA., Ginanjar, R. 2018. Hubungan Kebisingan dengan Keluhan Non Auditory Effect pada Pekerja Bagiab Weaving di PT. Unitex Bogor Tahun 2018. Jurnal Mahasiswa Kesehatan Mayarakat, 1(2), 74-79.

13] Fink, D. 2019. A New Definition of Noise: Noise Is Unwanted and/or Harmful Sound . Noise is The New 'Secondhand Smoke'. Proceeding of Meeting on Acoustics, 39(1), 1-12.

14] Gani, LR., Rachmawati, DA., Indreswari, L., Mardijana, A., Nurdian, Y. 2018. Hubungan antara Kebisingan di Tempat Kerja dengan Kualitas Tidur pada Pekerja Pabrik Kayu PT. Muroco Jember. Journal of Agromedicine and Medical Sciences, 4(2), 72-76.

15] Gunawan, B. A. \& Marsum. 2015. Deskripsi Intensitas suara pada Unit Raw Mill PT. Holcim Indonesia Tbk. Cilacap. Keslingmas, 34(1), 213-219.

16] Hernayanti, M. A., Tri, J. \& Hanan, L. D., 2018. Hubungan Kebisingan di Bandara Halim Perdana Kusuma Jakarta Timur terhadap Gangguan Non-Auditori Permukiman Penduduk Wilayah Buffer. Jurnal Kesehatan Masyarakat, 6(6), 214224.

17] Hill, EM. 2012. Noise sensitivity and diminished health: the role of stress-related factors. PhD Thesis. Aucland University of Technology.

18] Hadad, O., Prochaska, JH., Daiber, A., Munzel, T. 2019. Environmental NoiseInduced Effects on Stress Hormones, Oxidative Stress, and Vascular Dysfunction: Key Factors in the Relationship between Cerebrocardiovascular and Psychological
Disorders. Hindawi Oxidative Medicine and Cellular Longevity, 1, 1-13.

19] Hiola, R., Sidiki, AK. 2016. Hubungan Kebisingan Mesin Tromol dengan Stres Pekerja di Kabupaten Bone Bolango. Unnes Journal of Public Health, 5(4), 285-293.

20] Indriyanti, LH., Wangi, PK., Simanjuntak, k. 2019. Hubungan Paparan Kebisingan terhadap Peningkatan Tekanan Darah pada Pekerja. Jurnal Kedokteran dan Kesehatan, 15(1), 36-45.

21] Munzel, T., Schmidt, FP., Steven, S., Herzog, J., Daiber, A., Sorensen, M. 2018. Environmental Noise and The Cardiovascular System. Journal of the American College of Cardiology, 71(6), 688-697.

22] Nooruzian, M., Jafari, Z., Shahmiri, E., Omidvar, S., Zendehbad, AS., Amini, N., Bagherian, M., Radmehr, M., Yoonessi, A. 2017. Effect of Age, Gender and Hearing Loss on the Degree of Discomfort Due to Tinnitus. Basics and Clinical Neuroscience, 8(6), 435-442.

23] Panggeleng, AMF. 2018. Faktor Yang Berhubungan dengan Gangguan Fungsi Pendengaran Pekerja pada Bagian Produksi PT Makassar Tene. Skripsi. Universitas Hasanuddin.

24] Park, J., Chung, S., Lee., J., Sung JH., Cho, SW., Sim, CS. 2017. Noise Sensitivity, Rather than Noise Level, Predicts the NonAuditory Effect of Noise in Community Samples: A Population-based Survey. BMC Public Health, 17(1), 315.

25] Phillips, S.L., Henrich, V.C., Mace, S.T., P. 2010. Prevalence of noise-induced hearing loss in student musicians. International Journal of Audiology 49(4)309-16.

26] Pratiwi, S.J., Hemy, A., \& Silvia, K. 2013. Hubungan Antara Persepsi Terhadap Kebisingan Dengan Stres Karyawan. Jurnal Ecopsy 3 (1) : 38-41.

27] Rachmawati, I. A. 2015. Hubungan Antara Intensitas Kebisingan Dengan Keluhan Non Auditory Effect Di Area Turbin dan Boiler Pembangkit. Skripsi, p. Jember: Universitas Jember.

28] Rahayu, P. \& Pawenang, E. T. 2016. Faktor yang berhubungan dengan gangguan pendengaran pada pekerja yang terpapar 
bising di unit spinning i pt. Sinar pantja djaja semarang. Unnes Journal of Public Health, 5(2), 140-148.

29] Rakhmawati, A., Ramlan, D., Yulianto. 2018. Hubungan Intensitas Suara Mesin Produksi dan Lama Paparan dengan Ambang Dengar Pekerja Penggiling Padi di Desa Banjarsari Kecamatan Sumbang Kabupaten Banyumas Thun 2017. Kelingmas, 37(3), 240-245.

30] Rammsayer, TH., Troche, SJ. 2011. On Sex-related Differences in Auditory and Visual Sensory Functioning. Archives of Sexual Behavior, 41(3), 583-590.

31] Robbin, S. P. 2002. Mangement. 2 nd Ed. New Jersey : Prentice Hall Englewood Cliffs.

32] Sari, RYI. 2010. Pemakaian Alat Pelindung Diri sebagai Upaya dalamMemberikan Perlindungan bagi Tenaga Kerja di Ruang Cetak PT. Air Mancur. Palur. Laporan Khusus.Universitas Sebelas Maret.

33] Sriwahyudi, Naiem, M. F., Wahyuni \& Andi. 2014. Hubungan Kebisingan Dengan Keluhan Kesehatan Non Pendengaran Pada Pekerja Instalasi Laundry Rumah Sakit Kota Makassar. 1-11.

34] Sudirman et al., F. N. A. 2014. Keluhan Kesehatan Non Pendengaran Akibat Kebisingan pada pekerja Instalasi Gizi Rumah Sakit. Skripsi. Universitas Hasanuddin.
35] Darlani, S. 2017. Kebisingan dan Gangguan Psikologis Pekerja Weaving Loom dan Inspection PT. Primatexco Indonesia. Jurnal of Health Education, 2(2), 130-137.

36] Tang, J., Liao, Y. Kelly, BC., Xie, L., Xiang, YT., Qi, C., Pan, C., Hao, W., Liu, T., Zhang, F., Chen. 2017. Gender and Regional Differences in Sleep Quality and Insomnia: A General Population-based Study in Hunan Province of China. Scientific Report, 7, 1-9.

37] Tantana, O. 2014. Hubungan Antara Jenis Kelamin, Intensitas Bising, Dan Masa Paparan Dengan Risiko Terjadinya Gangguan Pendengaran Akibat Bising Gamelan Bali Pada Mahasiswa Fakultas Seni Pertunjukan. Thesis. Universitas Udayana. BIBLIOGRAPHY \ 1033

38] Wardani, R. W., Globila, N., Indah, L., \& Erwin, D. N. 2020. Kebisingan dan Keluhan Subjektif pada Pekerja Sebagai Upaya Pengendalian Noice Induced Permanent Threshold Shift (Nipts). Journal of Vocational Health Study 3 (1), 89-96.

39] Yang, W., Moon, HJ., Kim, MJ. 2017. Combined Effects Of Short-Term Noise Exposure And Hygrothermal Conditions On Indoor Environmental Perceptions. Indoor and Built Environment, 27(8), 11191133.

40] Zuhra, F. 2019. Pengaruh Kebisingan Terhadap Status Pendengaran Pekerja Di PT. Kian Keramik Mas Plant Gresik. Skripsi. Universitas Airlangga. 